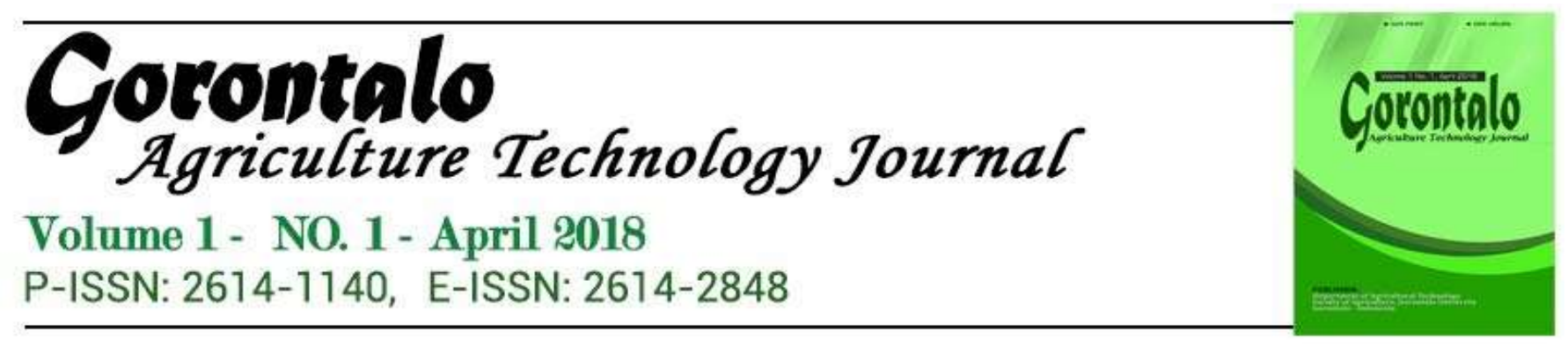

\title{
Pengaruh Penambahan Sukrosa Terhadap Mutu Organoleptik dari Selai Langsat
}

\author{
Rafika Yunus ${ }^{11}$ \\ ${ }^{1}$ Teknologi Hasil Pertanian Fakultas Pertanian Universitas Gorontalo \\ email: rafikayunus@yahoo.com
}

\begin{abstract}
jam is food products with the consistency of gel or semi solid made of pulp fruit. fruit langsat abundant in particular season, so that need to be further processed to reduce the fruit removed due to damage. the addition of sucrose expected to increase the taste and texture of jam langsat. this study aims to know obtain the formulation of the addition of sucrose (sugar) corresponding to obtain jam good. this study was conducted in the laboratory technology agricultural University gorontalo and in the laboratory Polytechnic gorontalo. this research was conducted in the form of the design of randomized complete (RAL) consisting of 3 treatment and 3 times replicates. from the results of this study, based test organoleptic treatment preferred by panelists is treatment a2 (sugar 65\%) with a score of color 3,9 (like), a sense of 4 (like), aroma 3,7 (like) and texture 4,1 (like)
\end{abstract}

Keywords : langsat, jam, sucrose, test organoleptic

\section{PENDAhUluan}

Indonesia merupakan salah satu negara penghasil aneka ragam buahbuahan. Mulai dari buah-buahan yang dapat diperoleh sepanjang tahun contohnya pisang, nanas, sirsak dan lain-lain, buah-buahan musiman misalnya mangga, durian, dan lain-lain ataupun buah-buahan yang berasal dari daerah dingin seperti stroberi dan apel.

Buah-buahan merupakan salah satu komoditi yang merudah mengalami kerusakan. Sifat yang mudah rusak dan busuk ini sering menimbulkan kerugian bagi pertani atau pedagang buah-buahan. Setiap jenis buah-buahan memiliki kerusakan yang berbeda-beda, yang kadang timbul pada saat pemanenan, penyimpanan, pengangkutan, ataupun pemasaran.

Pada dasarnya, buah-buahan dapat dimanfaatkan untuk berbagai jenis makanan olahan sehingga dapat dikonsumsi menjadi bentuk yang lain namun tetap memiliki gizi. Salah satu buah tersebut adalah buah langsat. Langsat merupakan salah satu buah musiman yang ada di Indonesia. Pada musim panen produksi langsat melimpah, harganya sangat murah dan langsat yang tidak habis terjual akan cepat layu, rusak dan busuk. Oleh karena itu buah 
langsat perlu di olah menjadi bahan makanan lain yang lebih awet, misalnya diolah menjadi selai, manisan, nectar, sari buah, sirup dalam sirup dan jelli.

Selai merupakan produk makanan dengan konsistensi gel atau semi padat yang dibuat dari bubur buah. Konsistensi gel atau semi padat pada selai diperoleh dari senyawa pektin yang berasal dari buah atau pektin yang ditambahkan dari luar, gula sukrosa dan asam. Interaksi ini terjadi pada suhu tinggi dan bersifat menetap setelah suhu diturunkan. Kekerasan gel tergantung pada konsentrasi gula, pektin dan asam pada bubur. Konsentrasi pektin terbaik dalam pembuatan selai adalah 1-1,5\% ( Hasbullah, 2007).

Menurut Subroto (2008), dalam kehidupan sehari-hari gula adalah sukrosa (disakarida). Dalam kehidupan sehari-hari gula sangat dibutuhkan untuk bahan makanan dan minuman. Pada makanan dan minuman gula tidak hanya digunakan sebagai pemanis, tetapi juga sebagai pengawet makanan dan minuman.

Masih kurangnya pemanfaat langsat saat ini sebagai bahan dasar dalam pembuatan selai, sehingga perlu dilakukan penelitian untuk mengetahui pembuatan selai langsat dengan menambahkan gula pasir dan pektin. Permasalahan yang banyak dihadapi pada pembuatan selai adalah banyaknya menentukan besarnya konsentrasi gula pasir yang harus ditambahkan agar dihasilkan selai langsat yang disukai konsumen. Gula yang ditambahkan pada pembentukan selai berfungsi sebagai dehydrating agent, yaitu menarik molekul-molekul air yang terikat dengan molekul-molekul air yang terikat dengan molekul pektin sehingga akan mempengaruhi keseimbangan pektin dan air yang ada sehingga kekukuhan dan kekenyalan selai dapat dipertahankan. Disamping itu gula pasir yang ditambahkan akan mempengaruhi terbentuknya gel, bila terlalu banyak maka akan terjadi kristalisasi pada permukaan gel tetapi bila gula yang ditambahkan kurang, maka gel yang terbentuk terlalu lunak.

\section{METODE PENELITIAN}

\subsection{Alat dan Bahan}

Alat yang digunakan dalam penelitian ini adalah alat-alat gelas, timbangan analitik, pisau, baskom plastik, kompor, panci, blender, dan pengaduk.

Bahan yang digunakan dalam penelitian ini adalah buah langsat, gula pasir (sukrosa), pektin dan air.

\subsection{Metode Penelitian}

Metode ini menggunakan metode rancangan acak lengkap (RAL) dengan substitusi asam sitrat dengan sari buah mangga Indramayu dan tiap perlakuan di lakukan tiga kali ulangan, di mana:

$\mathrm{A} 1=60 \%$ sukrosa

A2 $=65 \%$ sukrosa

A3 $=70 \%$ sukrosa 


\subsection{Prosedur Penelitian}

\section{Pembuatan Bubur Buah Langsat}

1. Buah langsat dipilih atau disortasi untuk memisahkan buah langsat dengan kualitas yang baik

2. Membuang bagian yang tidak akan digunakan

3. Langsat dicuci bersih dengan air mengalir

4. Kemudian dipotong kecil-kecil

5. Kemudian dilakukan penghalusan dengan menggunakan blender

\section{Pembuatan Selai Langsat}

1. Bubur buah langsat kemudian dipanaskan selama 3 menit

2. Kemudian ditambahkan konsentrasi sukrosa (gula pasir) sesuai perlakuan dan pektin $1,5 \%$

3. Kemudian dimasak hingga mengental selama \pm 25 menit

4. Kemudian didinginkan.

\subsection{Parameter Pengamatan}

Uji organoleptik (Rahayu, 2011) yang dilakukan meliputi tekstur, warna, aroma, dan rasa dari Selai langsat. Metode pengujian yang dilakukan metode hedonic (uji kesukaan). Sampel disajikan secara acak pada panelis, dengan jumlah panelis yang dibutuhkan sebanyak 25 orang. Kemudian panelis diminta untuk memberikan nilai menurut tingkat kesukaan. Skala hedonic yang digunakan yaitu :

1 = Sangat tidak suka

2 = Tidak suka

3 = Agak suka

4 = Suka

$5=$ Sangat suka

\section{HASIL DAN PEMBAHASAN}

Pengujian sensori atau pengujian dengan indera atau dikenal juga sebagai uji organoleptik sudah ada sejak manusia mulai menggunakan indranya untuk menilai kualitas dan keamanan suatu makanan dan minuman. Secara umum, uji organoleptik adalah cara menguji mutu komoditas dengan menggunakan kepekaan alat indra manusia sebagai alat pengukur/penguji (Setyaningsih et al. 2010).

\subsection{Organoleptik Warna}

Respon panelis terhadap warna dari selai langsat pada Gambar 1 menunjukkan warna selai langsat yang disukai adalah perlakuan penambahan gula pasir dengan konsentrasi 65\%, sedangkan warna selai langsat yang tidak disukai adalah perlakuan penambahan gula pasir dengan konsetrasi $70 \%$.

Hal ini disebabkan karena banyaknya konsentrasi gula pasir yang ditambahkan mempengaruhi warna pada selai. Warna selai langsat yang dihasilkan untuk konsentrasi gula pasir sebanyak $70 \%$ adalah coklat gelap sehingga memiliki skor 3,3 (agak suka), sehingga tidak disukai oleh panelis. Berbeda dengan warna selai langsat yang dihasilkan dari konsntrasi gula 
sebanyak $65 \%$, berwarna agak putih yang mendekati warna langsat aslinya sehingga masih disukai oleh panelis dengan skor 4 (suka).

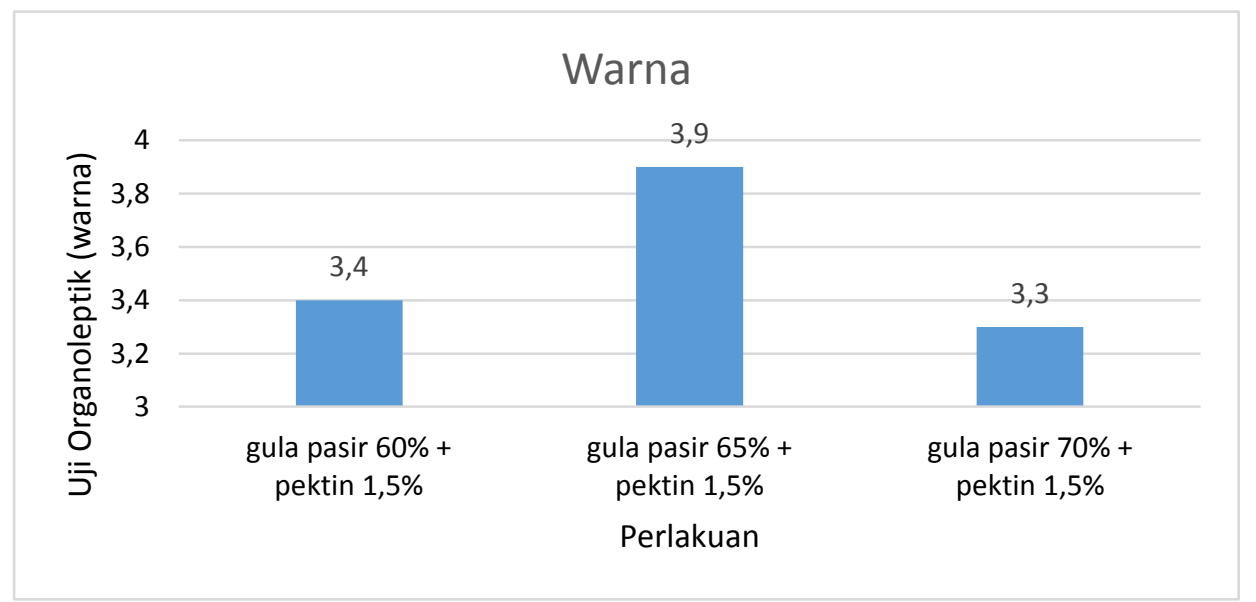

Gambar 1. Diagram Batang Organoleptik Warna pada Selai Langsat

Hal ini disebabkan karena pengatuh konsentrasi gula yang ditambahkan pada selai langsat. Melihat warna yang dihasilkan, semakin banyak konsentrasi gula yang ditambahkan maka warna yang dihasilkan semakin coklat. Hal ini disebabkan gula mempunyai sifat dapat menyebabkan reaksi pencoklatan yaitu karamelisasi. Hal ini sesuai dengan pendapat Winarno (2004), bahwa gula pasir yang diberikan perlakuan suhu tinggi akan mengalami proses karamelisasi. Karamel adalah substansi berasa berwarna coklat. Karamelisasi akan terjadi dengan mudah bila gula dipanaskan tanpa air dengan panas tinggi.

\subsection{Organoleptik Rasa}

Pada Gambar 2 terlihat respon panelis terhadap rasa dari selai langsat menunjukkan rasa selai langsat yang disukai dengan skor 4 (suka) adalah perlakuan penambahan gula pasir dengan konsentrasi 65\%, sedangkan rasa selai langsat yang tidak disukai dengan skor 3,2 (agak suka) adalah perlakuan penambahan gula pasir dengan konsentrasi $70 \%$.

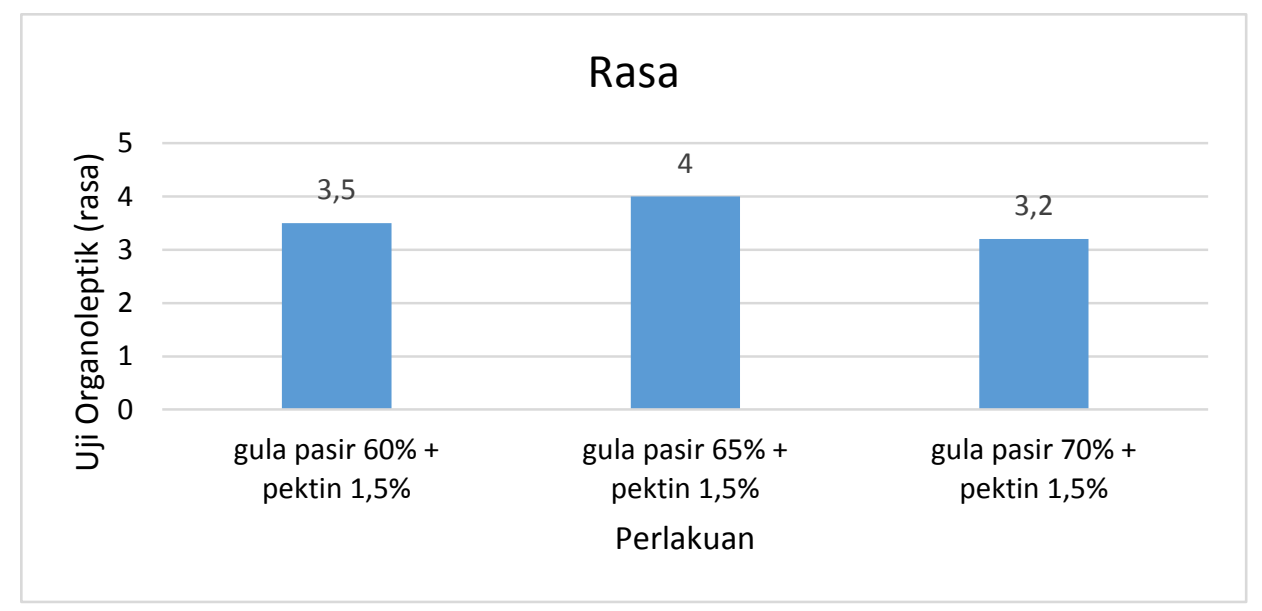

Gambar 2. Diagram Batang Organoleptik Rasa pada Selai Langsat 
Hal ini disebabkan karena banyaknya konsentrasi gula pasir yang ditambahkan pada selai. Rasa selai langsat yang dihasilkan untuk konsentrasi gula pasir sebanyak $70 \%$ adalah terlalu manis, sehingga tidak disukai oleh panelis. Berbeda dengan warna selai langsat yang dihasilkan dari konsntrasi gula sebanyak $60 \%$ dan $65 \%$, masing-masing memiliki rasa yang tidak terlalu manis sehingga masih disukai oleh panelis.

Hal ini disebabkan karena konsentrasi gula pasir yang ditambahkan pada selai langsat berbeda-beda, sehingga rasa manis yang timbul pada selai langsat juga berbeda. Semakin banyak konsentrasi gula apsir yang ditambahkan, maka semakin manis rasanya. Namun, tidak terlalu disukai oleh panelis jika terlalu manis. Hal ini sesuai dengan pendapat Yulistini et.al (2010), bahwa semakin tinggi penambahan sukrosa maka akan mempengaruhi rasa manis pada produk sehingga semakin disukai.

\subsection{Organoleptik Aroma}

Pembauan disebut juga pencicipan jarak jauh karena manusia dapat mengenal enaknya makanan yang belum terlihat hanya dengan mencium bau atau aroma makanan tersebut dari jarak jauh. Hasil uji organoleptik dari segi aroma dapat dilihat pada gambar berikut ini

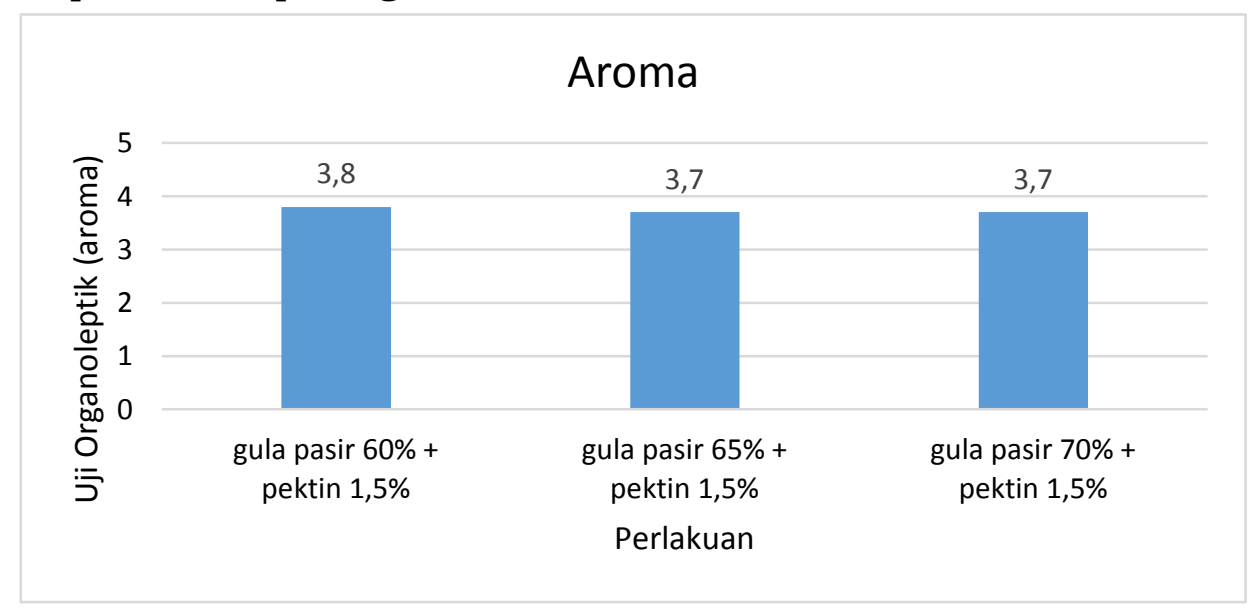

Gambar 3. Diagram Batang Organoleptik Aroma pada Selai Langsat

Pada Gambar 3 diatas memperlihatkan perbandingan uji organoleptik dari segi aroma pada selai langsat. Berdasarkan analisis ragam, perlakuan gula pasir dan pektin tidak memberikan pengaruh yang nyata terhadap aroma dari selai langsat. Dari Gambar 3 juga memperlihatkan penerimaan panelis secara keseluruhan menyukai aroma dari selai langsat dengan kisaran nilai 3,7-3,8 tanpa ada aroma khas lainnya lainnya. Hal ini disebabkan karena pektin dan gula pasir tidak memiliki aroma yang khas sehingga aroma selai langsat masih diterima oleh panelis.

\subsection{Organoleptik Tekstur}

Tekstur suatu bahan pangan merupakan salah satu sifat fisik dari bahan pangan yang penting. Hal ini berhubungan dengan rasa pada waktu mengunyah bahan pangan tersebut. Salah satu cara penentuan teskstur suatu bahan adalah dengan memberikan beban terhadap bahan tersebut misalnya 
dengan pemeriksaan bekas atau tekanan jari. Hasil uji organoleptik dari segi tekstur dapat dilihat pada

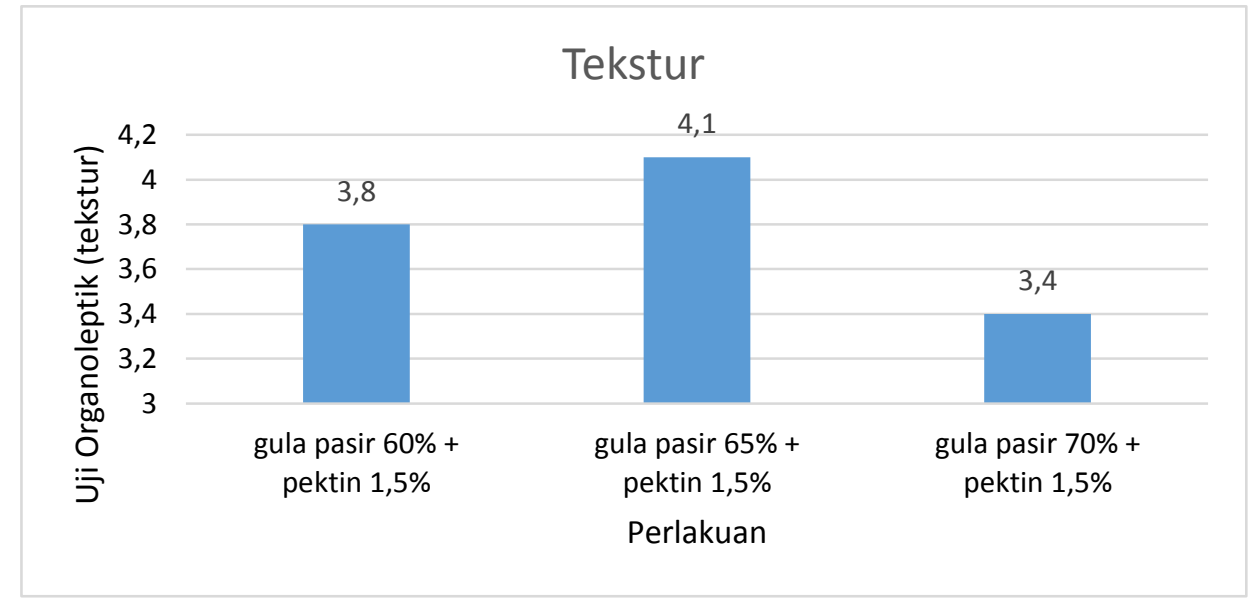

Gambar 4. Diagram Batang Organoleptik Tekstur pada Selai Langsat

Pada Gambar 4 terlihat bahwa berdasarkan penilaian panelis, tekstur selai langsat yang disukai adalah perlakuan dengan konstrasi gula pasir $65 \%$ (A2) yang memiliki skor 4,1 (suka). Berbeda dengan penilaian tekstur selai langsat yang tidak disukai oleh panelis adalah perlakuan dengan konsentrasi gula pasir 70\% (A3) yang memiliki skor 3,4 (agak suka). Perbedaan ini disebabkan karena tekstur dari selai langsat yang berbeda-beda. Pada perlakuan A3 memiliki tekstur yang cenderung masih agak encer dan tidak kasar seperti selai pada umumnya, sedangkan perlakuan A2 memiliki tekstur yang mirip seperti selai pada umumnya sehingga masih disukai oleh panelis. Hal ini disebabkan karena perbedaan kandungan air dari masing-masing perlakuan.

\section{KESIMPULAN DAN SARAN}

\subsection{Kesimpulan}

Berdasarkan uji organoleptik, perlakuan terbaik adalah perlakuan dengan konsentrasi gula pasir sebesar 65\% (A2) dengan skor warna 3,9 (suka), rasa 4 (suka), aroma 3,7 (suka) dan tekstur 4,1 (suka).

\subsection{Saran}

Saran yang dapat diberikan pada penelitian ini adalah sebaiknya melakukan penelitian lanjutan tentang umur simpan dari selai langsat dengan konsetrasi perlakuan gula pasir yang terbaik.

\section{REFERENSI}

Abriantoro, 2013. Praktek Produksi Selai Buah Naga Merah Kulit Merah

Daging Merah (Hylocereus Polyrhizus). Laporan Akhir. Universitas Sebelas Maret. Surakarta

Bait Y. 2012. Formulasi Permen Jelly Dari Sari Jagung Dan Rumput Laut.

Laporan Penelitian Berorientasi Produk Dana Pnbp Tahun Anggaran 2012.

Universitas Negeri Gorontalo. Gorontalo. 
Fahrizal Dan Fadhil R. 2014. Kajian Fisiko Kimia Dan Daya Terima Organoleptik Selai Nenas Yang Menggunakan Pektin Dari Limbah Kulit Kakao. Jurnal Teknologi Dan Industri Pertanian Indonesia. Vol 06 No 03.

Hasbullah. 2007. Otonomi Pendidikan (Kebijakan Otonomi Daerah Dan Implikasinya Terhadap Penyelanggaraan Pendidikan). Jakarta. Raja Grafindo Persada.

Subroto, A. 2008. Pemanfaatan Tepung Bekatul Rendah Lemak Pada Pembuatan Kripik Simulasi. Jurnal Gizi Dan Pangan, 2006 1:2, 34-44.

Winarno,F.G. 2004. Kimia Pangan Dan Gizi. Gramedia Pustaka Utama. Jakarta.

Yulistiani R, Murtiningsih Dan M Munifa, 2010, Peran Pektin Dan Sukrosa

Pada Selai Ubi. Prosiding Pada Seminar Pangan, Unpad, Bandung. 